\title{
ESTIMATING AOUIFER TRANSMISSIVITY FROM GEO-ELECTRICAL SOUNDING
}

\author{
Nasir Khalid Abdullahi ${ }^{1}$ and E. E. Udensi ${ }^{2}$ \\ 'Department of Applied Science, \\ Kaduna Polytechnic, \\ P.M.B.2021, Kaduna, Nigeria. \\ E-mail: nasirasman@yahoo.com \\ ${ }^{2}$ Department of Physics, \\ Federal University of Technology, \\ Minna, Niger State, Nigeria, \\ E-mail: eeudensi@yahoo.com
}

\begin{abstract}
A geophysical survey was carried out at Kaduna Polytechnic Senior Staff Quarters using Direct Current Electrical Resistivity method. The objectives were to determine different subsurface geoelectric layers, the aquifer units and the estimation of Transmissivity of the aquifer. Sixty-six Schlumberger Vertical Electrical Soundings (VES) were carried out using a maximum electrode separation of 200m. Data analysis and interpretation of the field curves by computer modeling proposes a distinctive 3-4 geoelectric layer situations. This includes the topmost layer which consists of laterite, river sand and gravel. This formation is followed in succession by clayey sand, weathered transition zone/ fractured layer and the fresh basement. Qualitative interpretation indicates that the weathered/fractured Basement constitutes the main aquifer unit. Aquifer resistivity range from $4.26 \mathrm{ohm}-\mathrm{m}$ to 755.3 ohm-m with maximum thickness of $52.25 \mathrm{~m}$. A maximum $55.52 \mathrm{~m}$ depth- tobasement was obtained in the study area. Based on the model obtained, aquifer Transmissivity was calculated and was used to delineate the study area into prospective low and high groundwater potential zones. In order to test the reliability of the results, the calculated Transmissivity values were compared with those obtained from pumping test analysis, and a linear regression coefficient of 0.94 was obtained.
\end{abstract}

\section{Introduction}

Sabo area of the southern part of Kaduna metropolis has witness an upsurge in infrastructural development and in human population in recent years. The demand for provision of potable water for human consumption and agricultural needs has grown tremendously over the years. Presently, the provision of potable water via metropolitan water supply scheme for the area is grossly inadequate for the needs of the people especially during the dry season. At this time of the year many rivers and streams in the area dry up and this creates problem of availability of water.

One of the common methods for evaluating aquifer characteristics such as Hydraulic conductivity and Transmissivity is pumping test, which however is very expensive and time consuming. Surface direct current (DC) resistivity measurements can provide rapid and effective techniques for aquifer characteristics evaluation. Works on these could be cited from previous studies (Niwas and Singhal, 1981; Mbonu et al, 1991; Dan- Hassan and Olorunfemi, 1999) Aquifer characteristics are important properties for determining the natural flow of water through aquifer, its response to fluid extracts, contaminants land assessments and for safe construction of civil engineering structures (Mbonu et al, 1991, Singh, 2005)

The objectives of this study were designed to determine different subsurface geoelectric layers, the aquifer units and to estimate aquifer Transmissivity from DC resistivity 
FUTY Journal of the Environment, Vol. 3 No.1, July 2008

(c) School of Environmental Sciences, Federal University of Technology, Yola - Nigeria.. ISSN 1597-8826

measurements in the Kaduna Polytechnic Bye-pass Senior Staff Quarters of Sabo area of Kaduna State of Nigeria.

\section{Geologic and Hydrologic Settings}

The study area lies approximately between latitudes $10^{\circ} 25^{\prime} \mathrm{N}$ and $10^{\circ} 30^{\prime} \mathrm{N}$ and longitudes $7^{\circ} 25^{\prime} \mathrm{E}$ and $78^{\circ} 30^{\prime}$ E covering an area of about $500,000 \mathrm{~m}^{2}$ (Fig. 1).

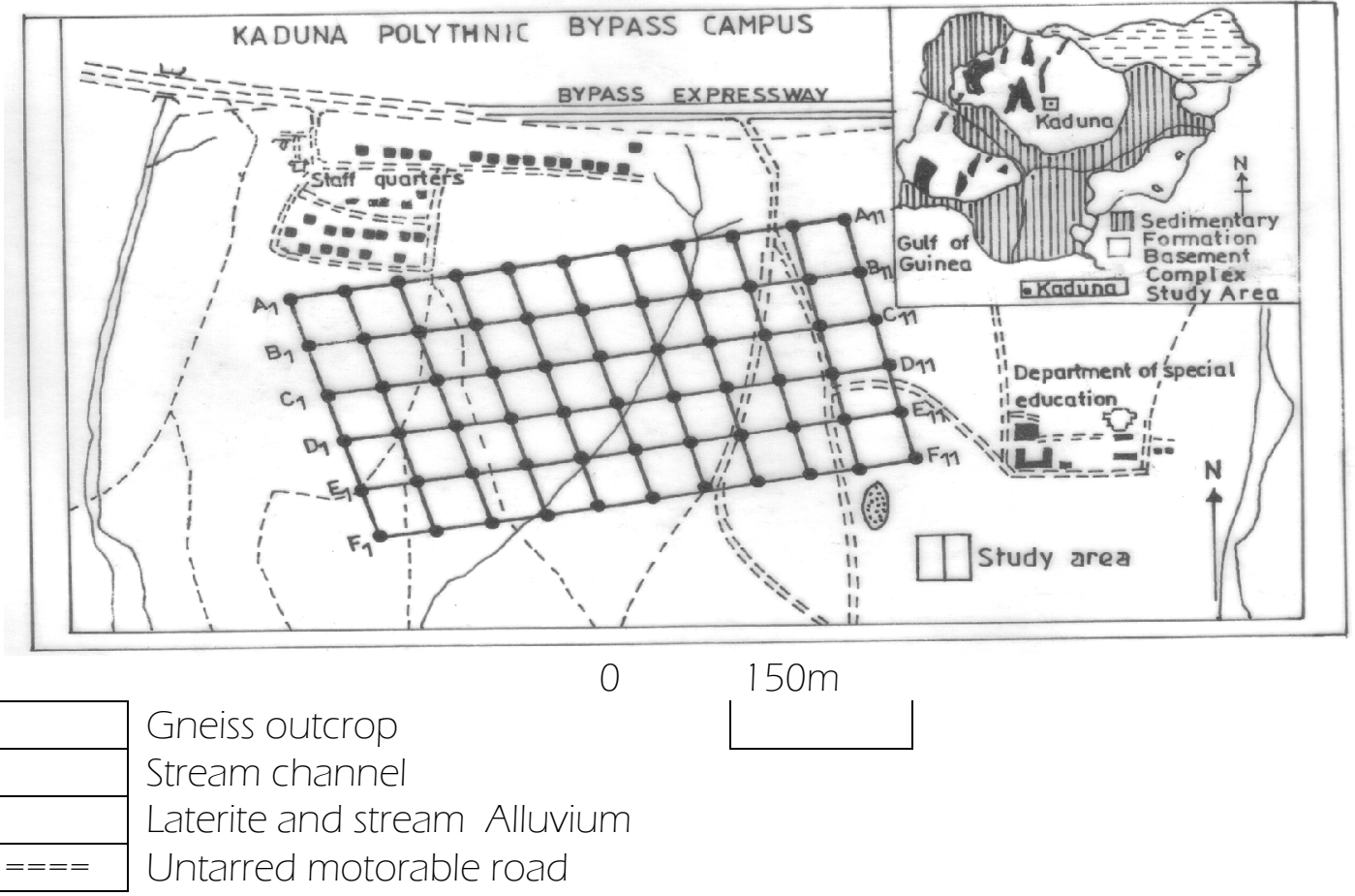

Fig. 1: Map of the Study Area.

The Precambrian basement complex rocks underlie the entire area of Kaduna and they consist of migmatite gneiss complex, metasediments/metavulcanics (mostly schist, quartzite, amphibolites and banded iron formation, pan African granitoids and calc-alkaline granites, and volcanics of Jurassic age (McCurry, 1976). A stream which forms part of River Kaduna draining system cut across all the profiles. The relief of the area ranges between 370 and 650m (Aboh, 2002: Mamman, 1992). Lower relief is occupied by the stream and river valley (Jatau, 1998). Groundwater in the area has not been adequately developed and as such data relating to their magnitude and mode of formation are lacking. However in the Basement complex, the permeability and storativity of the groundwater system are dependent on structural features such as the extent, and volume of fractures together with thickness of weathering (Eduvie, 1998; Clark, 1985). The relatively high annual rainfall $(1270 \mathrm{~mm})$ and temperature $\left(32^{\circ} \mathrm{C}\right)$ in Kaduna, which has resulted in the formation of deep weathered zone in addition to high density of fractures have contributed tremendously to constituting large reservoirs of groundwater, good aquifers and high yields of boreholes (Eduvie, 1998). Geophysical investigation and borehole drilling reports have clearly established two major aquifers. These are the overburden weathered aquifer and the fractured crystalline aquifer (Eduvie, 1998 and Dan-Hassan, 1999). Both aquifers at some places are interconnected and form a hydro geological unit of water table surface.

\section{Geo-electric Survey and interpretation}

Geophysical investigations consisting of 66 vertical electrical sounding (VES) using the schlumberger four-electrode array were taken within the study area. Six profiles numbered 
FUTY Journal of the Environment, Vol. 3 No.1, July 2008

( ) School of Environmental Sciences, Federal University of Technology, Yola - Nigeria.. ISSN 1597-8826

A-F were established covering an area of $0.5 \mathrm{~km}^{2}$. A station interval of $100 \mathrm{~m}$ was used to established the various sounding points along each profile by wooden pegs marked as $A_{1}$ - F 11 . The maximum half spread (AB/2) of current electrode was $100 \mathrm{~m}$ with the potential electrode $M N$ changing correspondingly from $0.5-15 \mathrm{~m}$. The measurements were made with ABEM 300C Terrameter units. 20mA was used in four staking to collect the data .Transmissivity evaluation based on hydraulic conductivity estimates can be erroneous if the saturated thickness and electrical resistivity of the aquifer are not interpreted accurately. Thus, to minimize aquifer thickness and resistivity interpretation error, field data were interpreted by using fast computer assisted program (INTERPEX, IXID).The VES curves reflect, geo-electrically a three and four-layer curve types, with a maximum fitting error of 7.59\% between the observed and computed VES data, Fig 2 shows representative sounding and the inverted model .
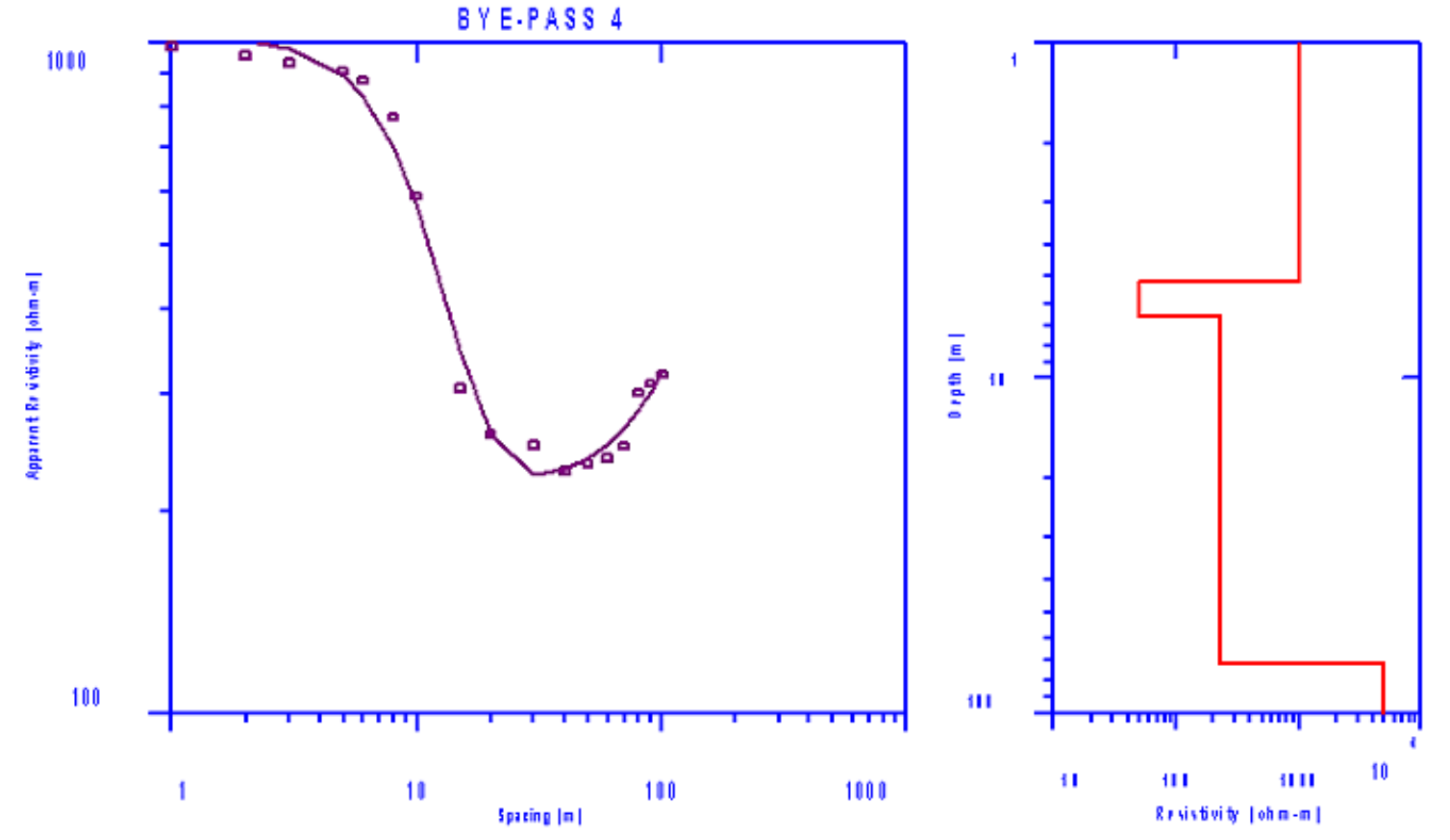

Fig. 2. Typical computer interpretation for $V E S D_{4}$

\section{Interpretation of Geo-electric sections}

Geologic sections were constructed using the results of the VES and geologic data obtained from the works of Dan- Hassan, (1999) and Eduvie, (2003). The VES interpretation suggested that the layering in the area varies from 3 to 4 . Deductions from borehole log after Dan- Hassan, (1999) and Eduvie, (2003) in the area suggests that the top most layers consists of laterite, river sand and gravel. The resistivity value varies from 250 ohm-m to 3000ohm-m, while the thickness varies between $3 \mathrm{~m}$ to $9 \mathrm{~m}$. The second layer has resistivity values between $200-700$ ohm-m. It typifies clayey sand and has thickness between $6 \mathrm{~m}$ to $18 \mathrm{~m}$. The derived geologic sections suggest that the third layer, which consists mostly of weathered transition zones, have resistivity values between 14.26 ohm-m to 750 ohm-m. It has a maximum thickness of 55.52m and a minimum thickness of $0.67 \mathrm{~m}$. The resistivity of the basement, which either forms the $3^{\text {rd }}$ or $4^{\text {th }}$ layer, ranges from 630 ohm-m to 10000 ohm-m. The relatively low resistivity value $(<1000$ ohm-m) of the basement rock beneath some VES points represents fractures in the crystalline bedrock. The thickness is infinite. Basement aquifers occur within the weathered residual overburden (regolith) and the fractured bedrock, thus, the weathered transition zone/ fractured bedrock form the aquifer units in the study area. Fig 3 shows the interpretated geo-electric sections of $\operatorname{VES} A_{1}-A_{3}$ 


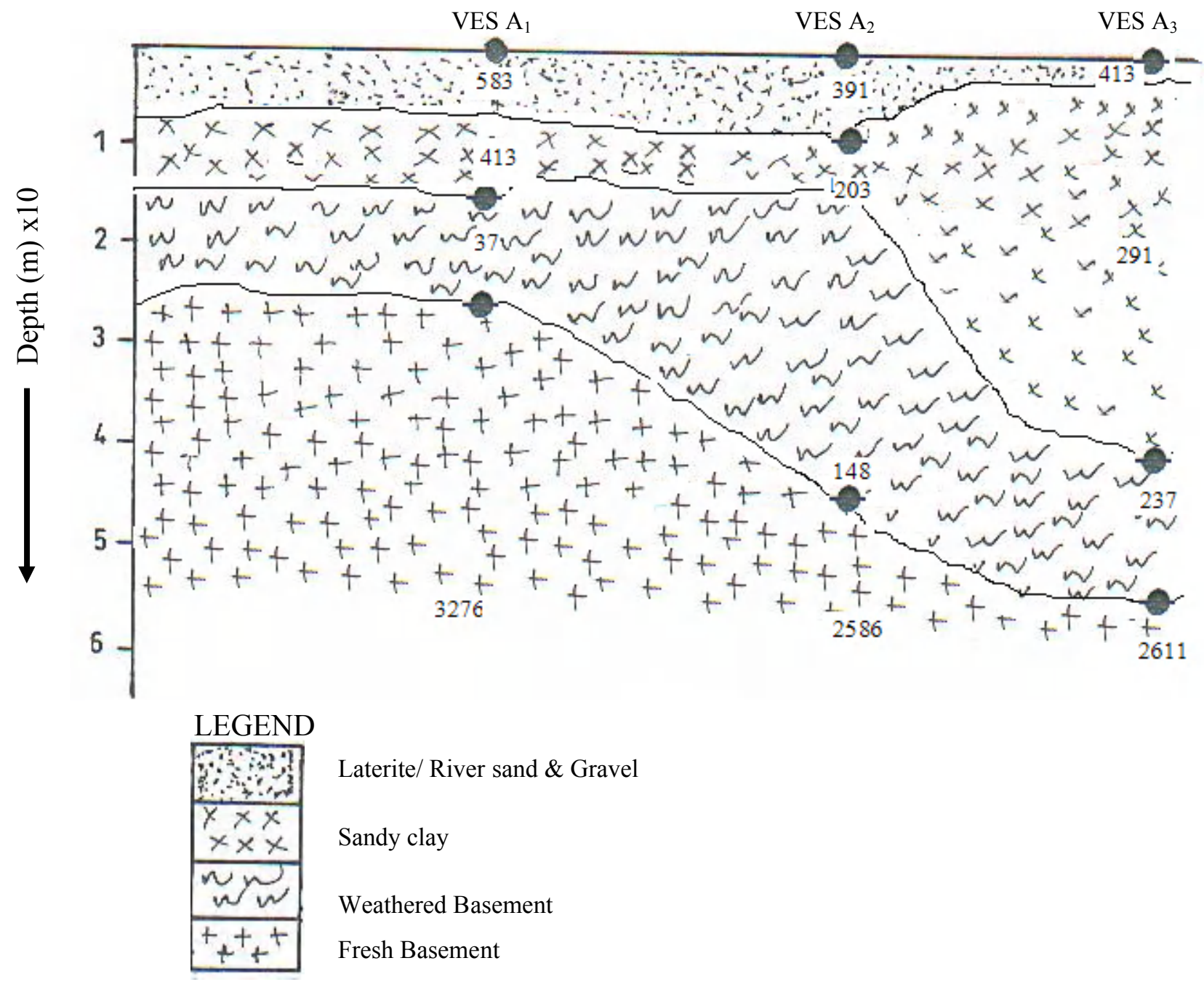

Fig. 3: Interpreted Geologic Section for VES $A_{1}, A_{2} \& A_{3}$

Evaluating Transmissivity of the Aquifer

Niwas and Singhal (1981) studied the relationship between hydraulic parameters and electrical parameters. They showed that as reported by (Dan-Hassan et al, 1999) in a porous medium

$$
T=K \sigma R=K S \rho=K h
$$

Where $T$ is the Transmissivity, $K$ is the hydraulic conductivity, $\sigma$ the layer conductivity, $R$ the transverse resistance, $S$ longitudinal layer conductance, $\rho$ layer resistivity and $h$ the thickness of the aquifer respectively. According to Niwas and Singhal (1981) the practical applicability of equation 1, lies in the fact that by knowing the values of $\mathrm{K}$ from existing boreholes, one can estimate the Transmissivity of the aquifer from the transverse resistance and conductivity of the aquifer obtained from resistivity measurements at other locations within a basin. Using an average hydraulic conductivity of $0.61 \mathrm{~m}^{1}$ day $^{-1}$ from 60 existing boreholes within Igabi, Kaduna North, Kaduna South and Chikun Local Governments Areas (Dan-Hassan et al, 1999 and Eduvie, 2003), Transmissivity of the aquifer in the study area was calculated using the relation $T==K \sigma R$ Table 1 shows the calculated Transmissivity values. 
FUTY Journal of the Environment, Vol. 3 No.1, July 2008

(0) School of Environmental Sciences, Federal University of Technology, Yola - Nigeria.. ISSN 1597-8826

Fig 4 shows the frequency distribution of the Hydraulic conductivity of the 60 existing boreholes considered while Fig 5 shows the corresponding Transmissivity values.

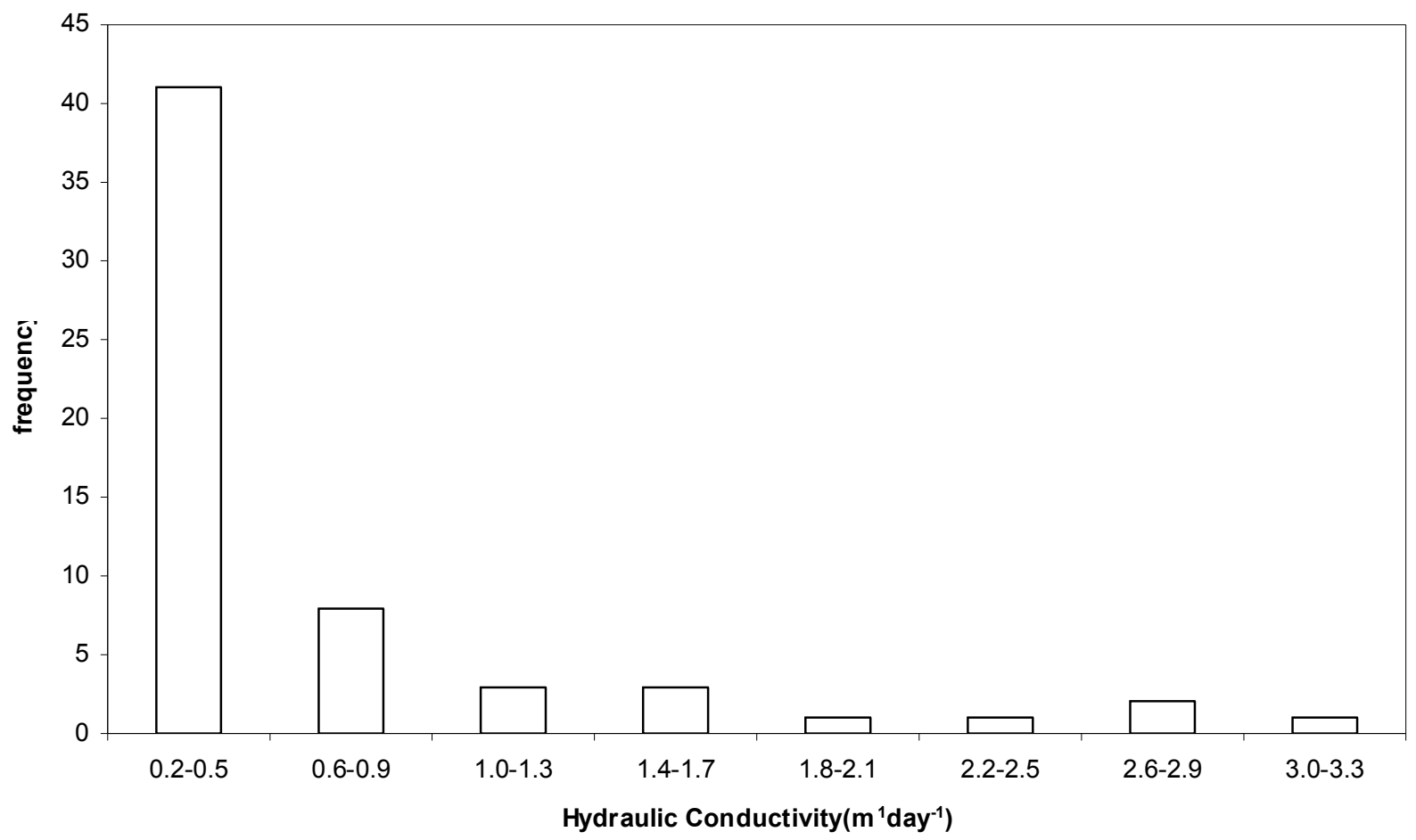

Fig 4 frequency distribution of hydraulic conductivity of existing boreholes 


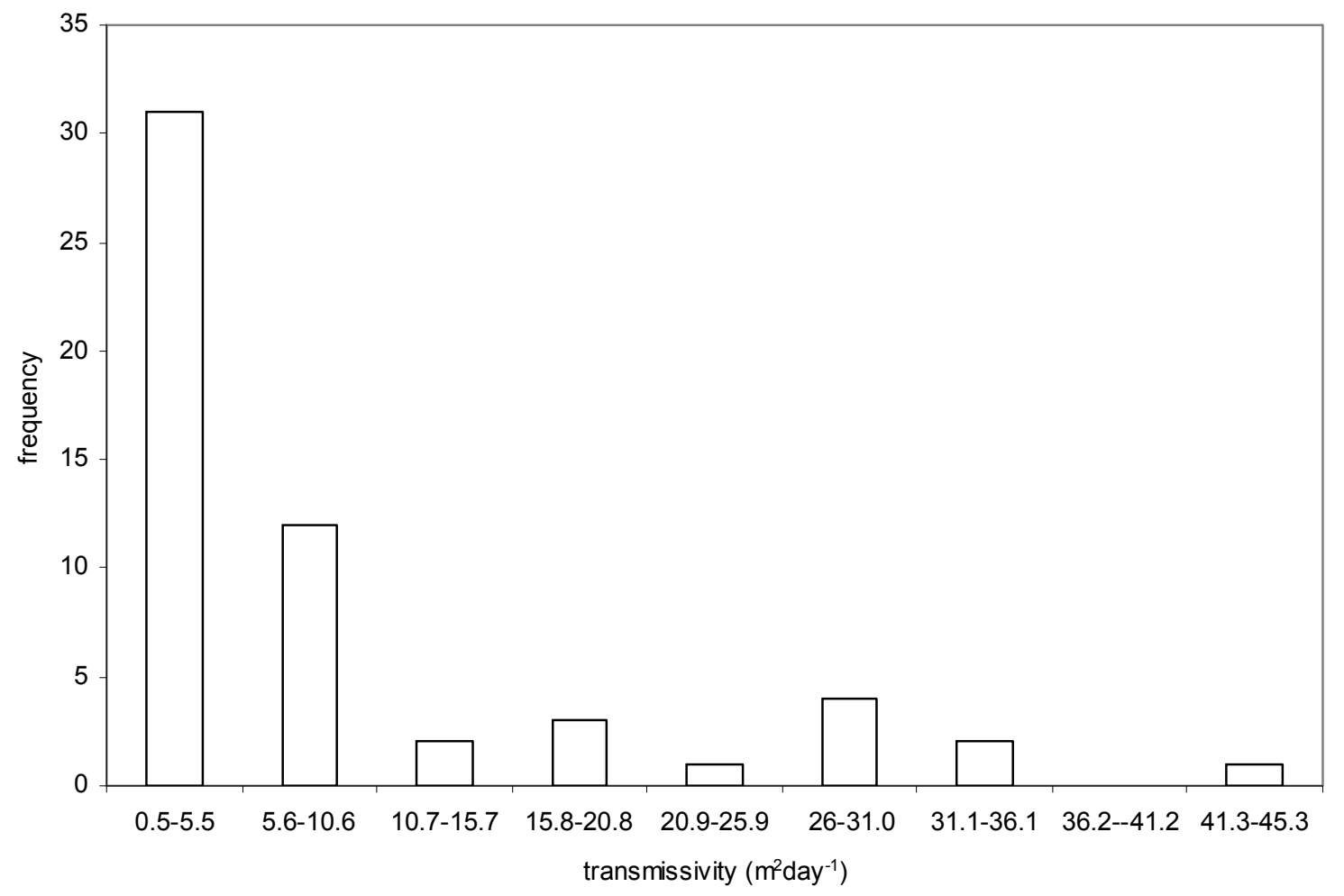

FIG 5 frequency distribution of Transmissivity from pumping test

\section{Results and Discussion}

Fig 6 shows the isopach map of the aquiferous layer (Weathered basement). The map plotted with Surfer (version 8.01) shows that the aquifer is highly variable in thickness, being thinnest in the vicinity of VES $E_{7}$ with thickness value of $0.64 \mathrm{~m}$ while VES $D_{10}$ with a value of $55.52 \mathrm{~m}$ forms the thickest point in the survey area. This result agrees with DanHassan and Olorunfemi (1999).Their result reports the thickness of the weathered layer ranging from 3-55m. Generally, with the exception of the North-Eastern and South-Eastern parts of the survey area, the survey area appears thick enough for drilling productive boreholes over the entire area with values ranging from $15-56 \mathrm{~m}$. 
FUTY Journal of the Environment, Vol. 3 No.1, July 2008

(c) School of Environmental Sciences, Federal University of Technology, Yola - Nigeria.. ISSN 1597-8826

Table 1 Calculated Transmissivity Values

\begin{tabular}{|c|c|c|c|c|c|}
\hline VES NO & $\begin{array}{l}\text { Transmissivity } \\
\left(\mathrm{m}^{2} \text { dayy }^{-1}\right)\end{array}$ & VES NO & $\begin{array}{l}\text { Transmissivity } \\
\left(\mathrm{m}^{2} \text { day }^{-1}\right)\end{array}$ & VES NO & $\begin{array}{l}\text { Transmissivity } \\
\left(\mathrm{m}^{2} \mathrm{day}^{-1}\right)\end{array}$ \\
\hline$\overline{A_{1}}$ & 8.97 & $B_{10}$ & 11.36 & $D_{8}$ & 21.89 \\
\hline$A_{2}$ & 9.74 & $B_{11}$ & 12.99 & $\mathrm{D}_{9}$ & 12.93 \\
\hline $\mathrm{A}_{3}$ & 33.11 & $C_{1}$ & 2.65 & $D_{10}$ & 52.16 \\
\hline $\mathrm{A}_{4}$ & 0.07 & $C_{2}$ & 29.11 & $D_{11}$ & 12.81 \\
\hline $\mathrm{A}_{5}$ & 5.79 & $C_{3}$ & 8.52 & $E_{1}$ & 11.69 \\
\hline$A_{6}$ & 20.49 & $\mathrm{C}_{4}$ & 10.97 & $\overline{E_{2}}$ & 7.97 \\
\hline$A_{7}$ & 26.03 & $C_{5}$ & 13.20 & $E_{3}$ & 12.49 \\
\hline$A_{8}$ & 7.30 & $\mathrm{C}_{6}$ & 20.03 & $E_{4}$ & 8.28 \\
\hline$A_{9}$ & 3.40 & $C_{7}$ & 21.24 & $E_{5}$ & 5.77 \\
\hline$A_{10}$ & 22.10 & $\mathrm{C}_{8}$ & 12.63 & $E_{6}$ & 5.89 \\
\hline$A_{11}$ & 22.65 & $C_{9}$ & 14.16 & $E_{7}$ & 1.11 \\
\hline $\mathrm{B}_{1}$ & 2.23 & $C_{10}$ & 14.35 & $E_{8}$ & 8.68 \\
\hline $\mathrm{B}_{2}$ & 22.67 & $C_{11}$ & 11.28 & E9 & 6.40 \\
\hline $\mathrm{B}_{3}$ & 15.21 & $\mathrm{D}_{1}$ & 18.84 & $E_{10}$ & 1.37 \\
\hline $\mathrm{B}_{4}$ & 38.08 & $D_{2}$ & 10.54 & $E_{11}$ & 23.00 \\
\hline $\mathrm{B}_{5}$ & 10.70 & $D_{3}$ & 7.59 & $F_{1}$ & 4.60 \\
\hline $\mathrm{B}_{6}$ & 15.44 & $\mathrm{D}_{4}$ & 16.20 & $\mathrm{~F}_{2}$ & 9.54 \\
\hline$\overline{B_{7}}$ & 7.85 & $D_{5}$ & 2.25 & $F_{3}$ & 4.54 \\
\hline $\mathrm{B}_{8}$ & 7.43 & $D_{6}$ & 6.64 & $\mathrm{~F}_{4}$ & 3.91 \\
\hline $\mathrm{B}_{9}$ & 19.88 & $D_{7}$ & 8.36 & $F_{5}$ & 2.44 \\
\hline$F_{6}$ & 2.38 & $F_{8}$ & 5.35 & $F_{10}$ & 1.57 \\
\hline $\mathrm{F}_{7}$ & 3.03 & $F_{9}$ & 9.97 & $F_{11}$ & 6.50 \\
\hline
\end{tabular}


FUTY Journal of the Environment, Vol. 3 No.1, July 2008

(c) School of Environmental Sciences, Federal University of Technology, Yola - Nigeria.. ISSN 1597-8826

The corresponding resistivity map of the aquiferous layer (Weathered Basement) (Fig 7) shows that the resistivity value ranges from 100-300 ohm-m in the Northwestern and Southwestern zones and 300-900 ohm-meter in the Northeastern and Southeastern parts of the survey area respectively. According to Odusanya and Amadi, (1990) reported by Dan-Hassan (1999), the electrical resistivity of this layer which forms the water bearing zone depends on the sand to clay ratio and degree of saturation. The zones with resistivity $>100$ ohm-m is characteristics of clayey-sand and sand and it indicates good aquifer formation while the lower end (<100 ohm-m) typifies clay which lowers the aquifer potentials. . However, according to Mbonu et, al (1991), isoresistivity map is a qualitative interpretation tool which shows possible variations in resistivity at a given electrode spacing and does not give the true resistivities of a definite geoelectric layer. The high resistivity values (> 400 ohm-m) recorded in profiles $E$ and $F$ is due to basement (Young Granite) intrusion. Profiles $E$ and $F$ are 102 and $2 \mathrm{~m}$ away from where the basement rock outcropped respectively.

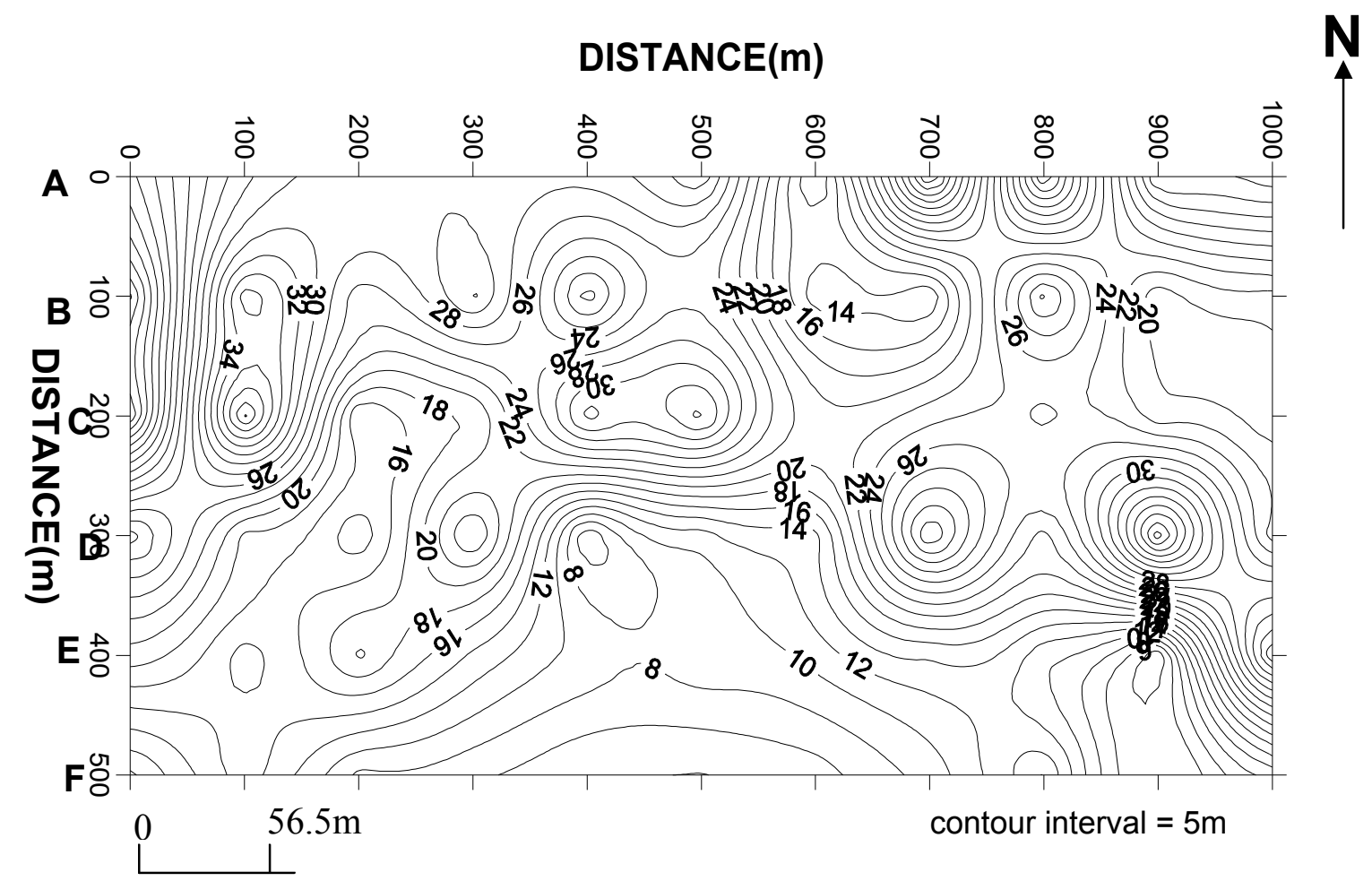

Fig. 6. Acquifer Isopatch Map 


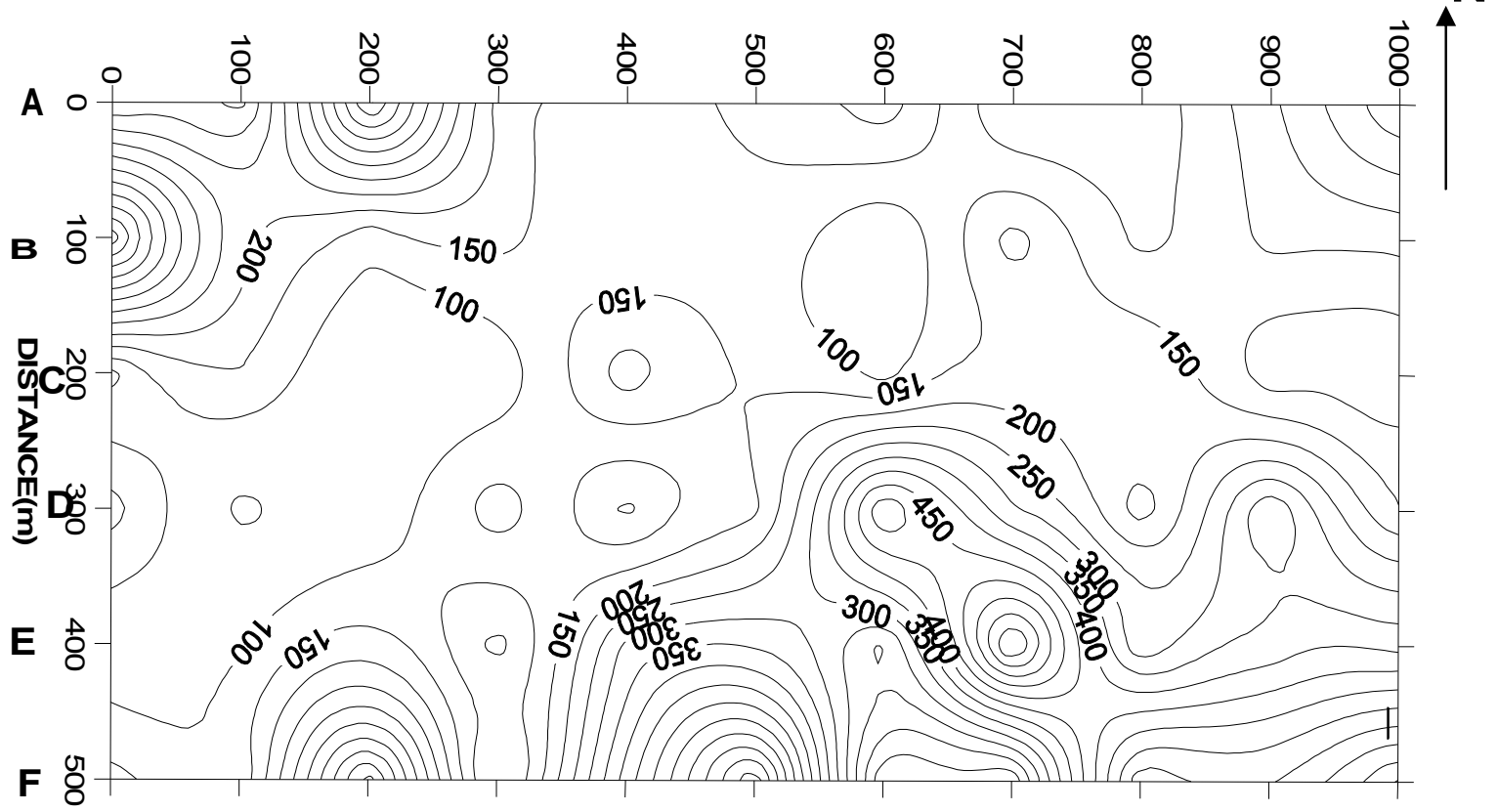

$\stackrel{56.5 \mathrm{~m}}{\perp} \quad \stackrel{2}{\perp}$ Fig Weathered Basement Iso-resistivity Map

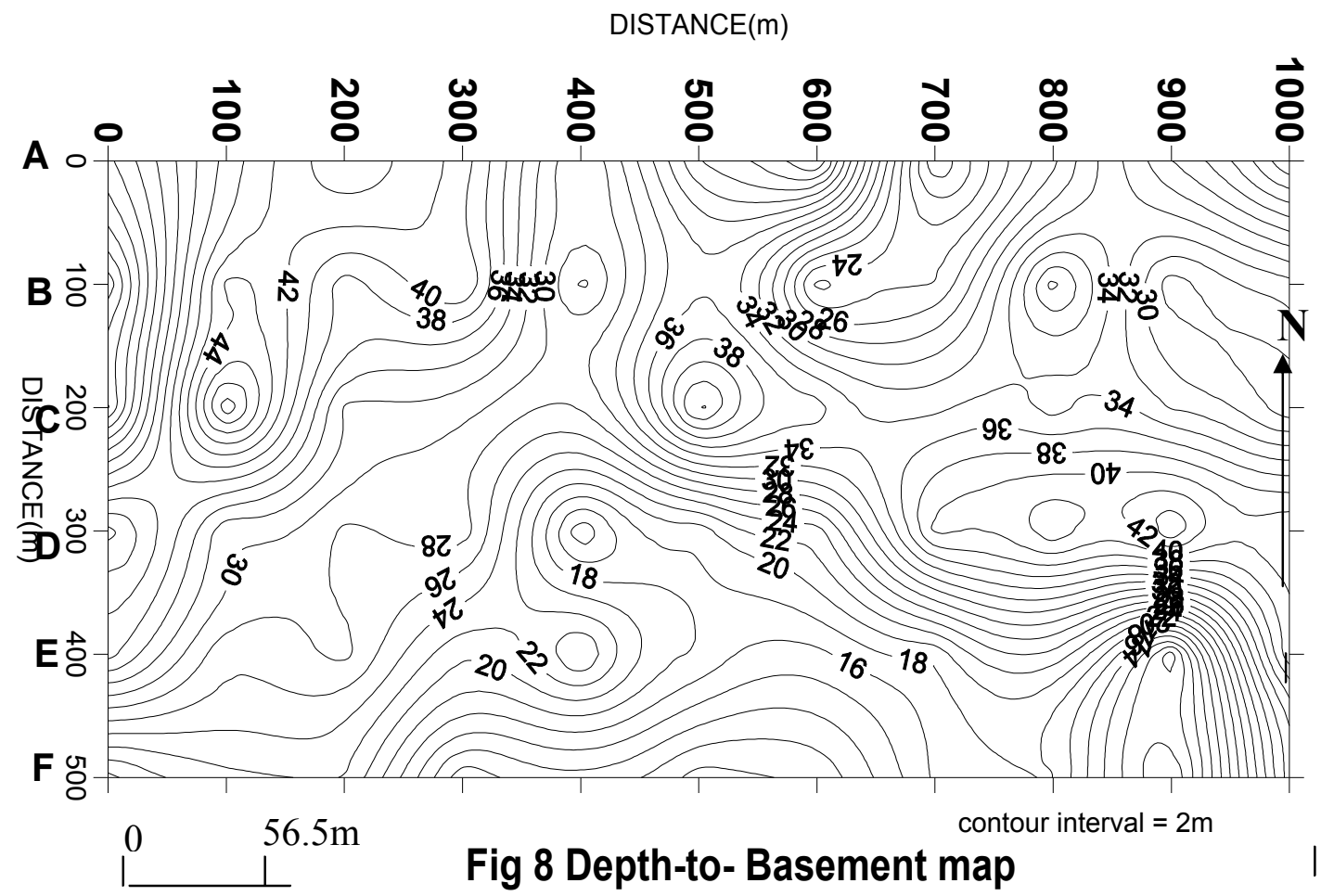

Figure 8 shows the depth -to-basement map. The map was produced by summing topsoil, clayey sand layer and the weathered/fractured basement layer. It varies between $5.98 \mathrm{~m}$ at $F_{10}$, which correspond to basement highs/ $F_{10}$ is $2 \mathrm{~m}$ where the basement outcropped) to $55.52 \mathrm{~m}$ at $\mathrm{D}_{10}$, the deepest point in the study area which correspond to basement depression. This agrees with the results of $4.3-64 \mathrm{~m}$ depth reported by DanHassan and Olorunfemi (1999). The overburden is deep in the Northcentral, Northwest and extreme Eastern sections of the study area. The average depth-to-basement in these 
FUTY Journal of the Environment, Vol. 3 No.1, July 2008

(c) School of Environmental Sciences, Federal University of Technology, Yola - Nigeria.. ISSN 1597-8826

zones is about $32 \mathrm{~m}$. The overburden in the Southeast of the study area is shallow with an average depth of $12 \mathrm{~m}$. Figure 9 shows the calculated Transmissivity of the aquifer. Comparison of this figure with (Fig 6) shows that areas underlain by relatively thick aquifer materials have high Transmissivity values than areas underlain by relatively thin materials. This relationship is expected because Transmissivity is a function of thickness i.e. Transmissivity increases with thickness. The calculated Transmissivity values are high over most of the Northwestern and Southwestern parts of the survey area with values between $8-52 \mathrm{~m}^{2}$ day $^{-1}$. These are the zones where aquifer resistivity values ranged between 100$150 \mathrm{ohm}-\mathrm{m}$ and therefore the groundwater condition in these zones are potentially high..

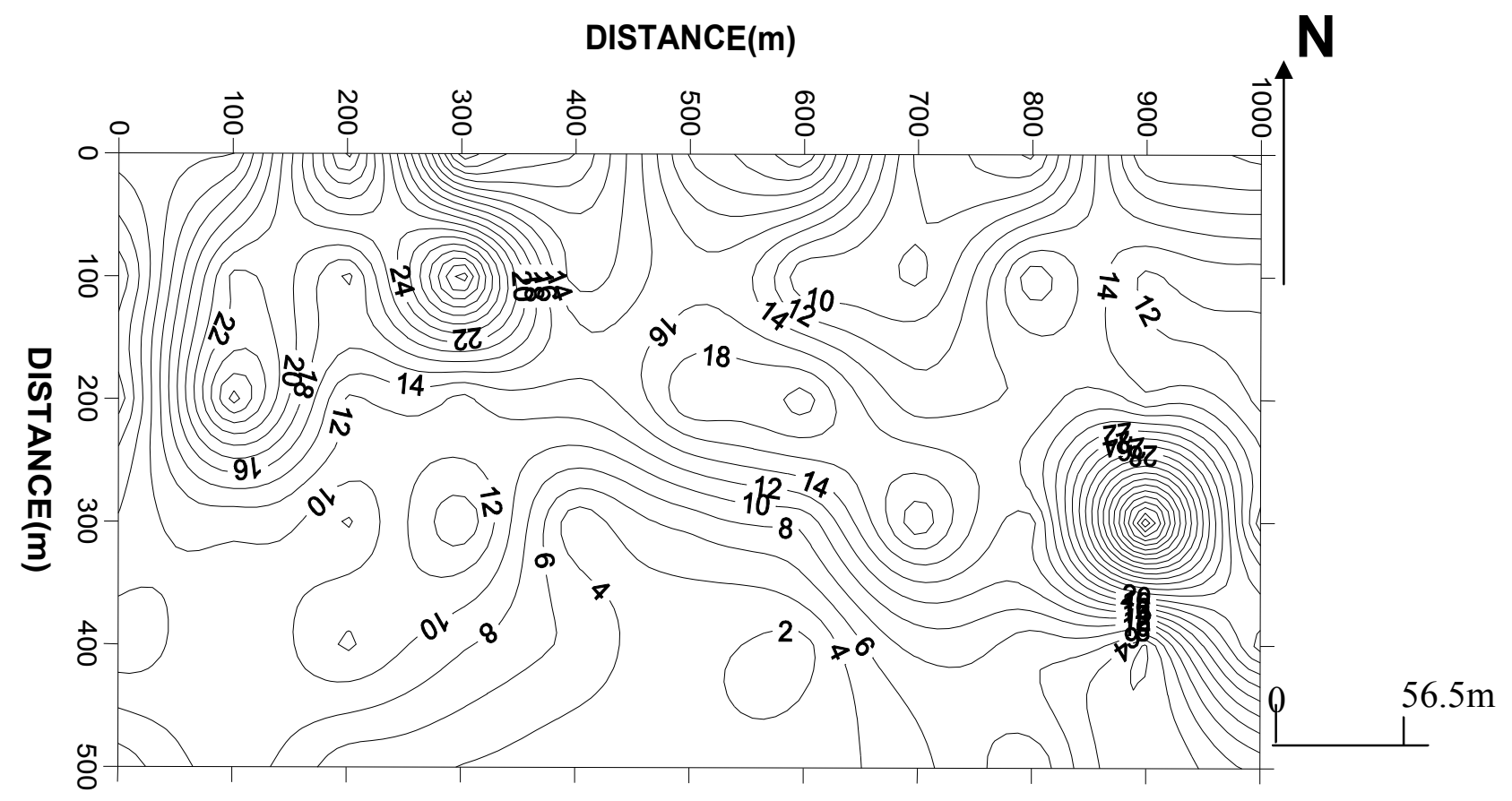

Fig 9 Calculated Transmissivity Map

Fig 10 is the distribution of the calculated Transmissivity with highest value of $52.16 \mathrm{~m}^{2}$ day and lowest value of $1.11 \mathrm{~m}^{2}$ day ${ }^{-1}$. The calculated Transmissivity values are generally higher than those obtained from pumping test (Fig 5) because they were calculated for the whole saturated thickness of the aquifer while those from pumping test analysis were obtained from the screened section of the aquiferous zones. A correlation analysis between the calculated Transmissivity from VES data and fifty (50) from pumping test analysis, (Fig 11), suggested that they are linearly related with a correlation coefficient of 0.94 . 


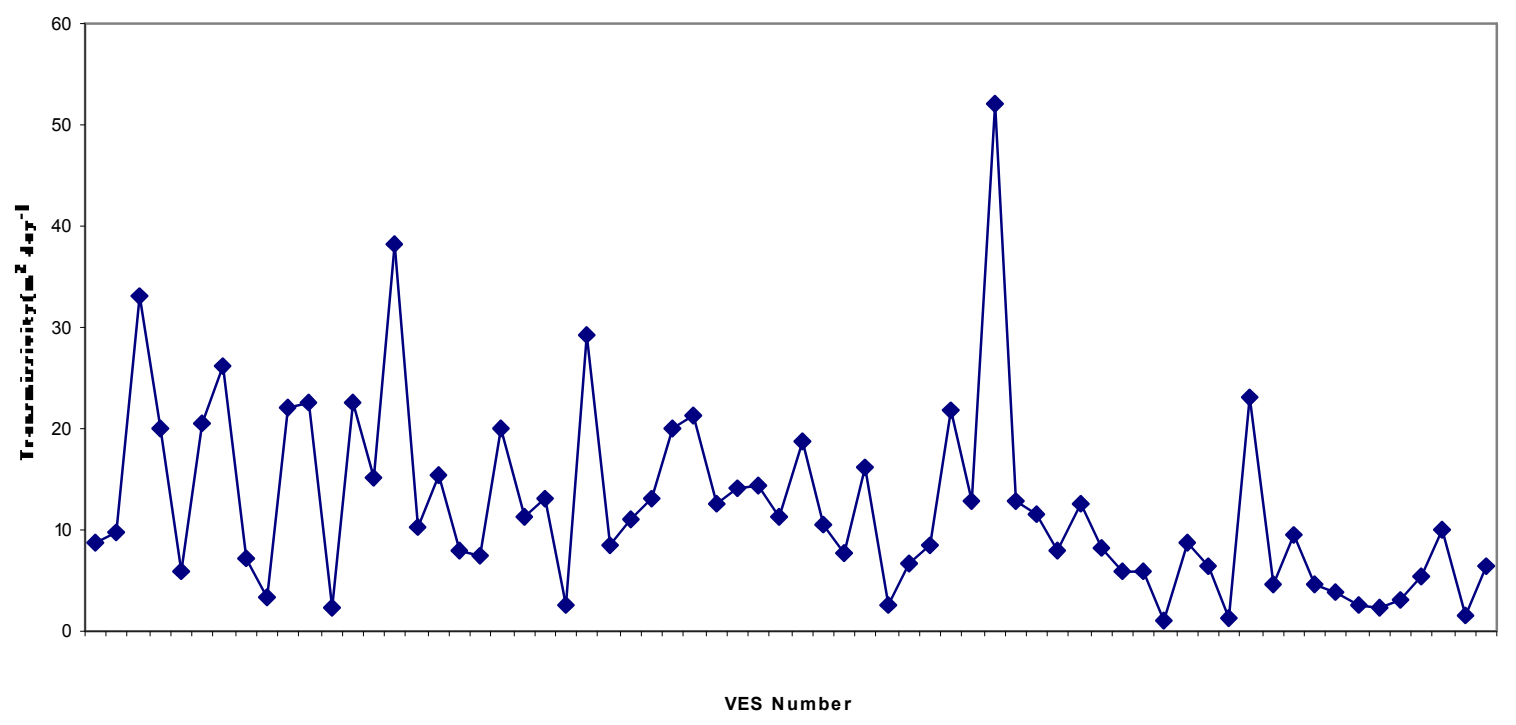

Fig 10 Distribution of Calculated Trans missivity

CAL_TRAN vs. P_TRANS (Casewise MD deletion)

P_TRANS $=-1.976+.92274 *$ CAL_TRAN

Correlation: $r=.94287$

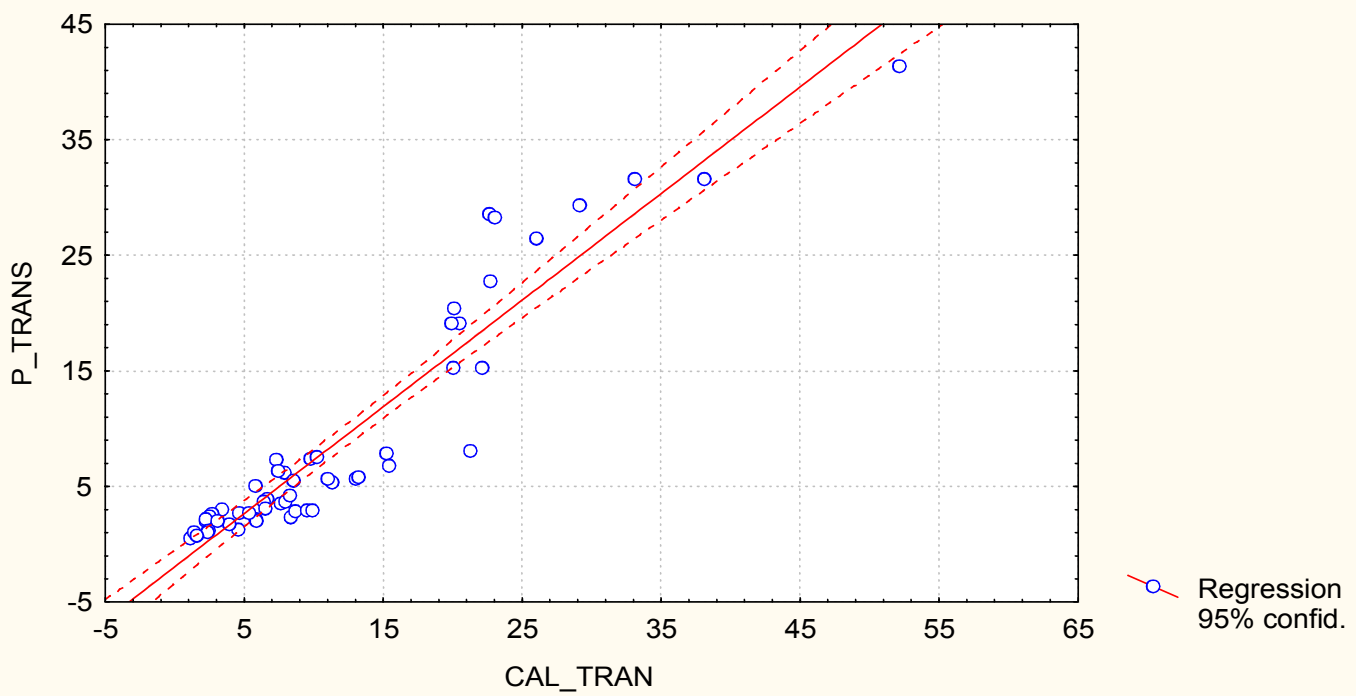

Fig 11 Linear regression correlation of Transmissivity from pumping test(P-TRANS) and calculated Transmissivity from VES data (CAL-TRANS) .

The dashed lines represent least-square's fit while the solid lines represents the regression correlation.

\section{Conclusion}

A total of sixty-six (66) VES stations were established. These were located on six profiles with Azimuth in the East-West direction. The interpretation of the VES data has enabled the derivation of four geologic units. The uppermost layer consists of laterite, river sand and gravel. This formation is followed in succession by clayey sand, weathered transition zone/ fractured layer and the fresh basement. The weathered transition zone/fractured basement constitutes the main aquifer unit in the study area. The isopach map of the weathered basement aquifer in the study area varies from $0.64 \mathrm{~m}$ to $55.52 \mathrm{~m}$ while the 
FUTY Journal of the Environment, Vol. 3 No.1, July 2008

corresponding aquifer resistivity ranges from $14.26-755.3 \Omega \mathrm{m}$. The depth-to-basement varies between 5.17 - 55.52m. Areas with thick overburden (>30m) correspond to basement depression while the zones with relatively thin overburden correspond to basement highs. Transmissivity values calculated vary from $1.11 \mathrm{~m}^{2}$ day ${ }^{-1}$ to $52.16 \mathrm{~m}^{2}$ day 'for the entire saturated thickness of the aquifer. Higher values of the calculated Transmissivity correspond with areas underline by relatively thick aquifer materials.

The present study has revealed that aquifer electrical properties can be converted into Transmissivity and human error and computation time in the interpretation of the VES data can be minimized by using fast inversion computer packages This transformation can be used as valuable information in finding suitable sites for the exploitation of groundwater and construction of safe civil engineering structures in the study area. A correlation coefficient of 0.94 obtained between the calculated Transmissivity and those obtained from pumping test analysis suggest close agreement between the two values.

\section{Acknowledgements}

The authors are grateful to the Department of Mining Resources Engineering, Kaduna Polytechnic for providing the SAS 300C Terrameter free during the collection of data, Iliyasu Yusuf of the Department of Mathematics, Statistics and Computer Science, Kaduna Polytechnic for his help in the statistical analysis of the results of this research. 
FUTY Journal of the Environment, Vol. 3 No.1, July 2008

(c) School of Environmental Sciences, Federal University of Technology, Yola - Nigeria.. ISSN 1597-8826

\section{References}

Aboh, H.O. (2002): Geotechnical characterization of subsurface materials in Kaduna area, Kaduna State, Nigeria. Zuma Journal of Pure \& Applied Science, 4(2)

Clark, L.M. (1985): Groundwater abstraction from the Basement Complex areas of Africa: O.J. Eng. Geol, vol. 18, 25-34

Dan-Hassan, M.A. and Olorunfemi, M.O. (1999): Hydro-Geophysical investigation of a basement terrain in the North-Central part of Kaduna State, Nigeria, Journal of Mining and Geology. vol 35(2). 189-206

Eduvie, M.O. (1998): Groundwater Assessment and Borehole Characteristics, Case Study from Parts of Kaduna Metropolis: Paper Presented at a Workshop Organized by Kaduna State Water Board. Nigeria Teachers Institute.

Eduvie, M.O. (2003): Exploration, Evaluation and Development of groundwater in Southern Kaduna State, Nigeria: unpublished PhD thesis, Department of Geology, A.B.U., Zaria

Odusanya, B.O. and Amadi, U.M.P. (1990): An empirical resistivity model for predicting Shallow groundwater occurrence in the Basement complex. Water Resources Journal of Nigerian Association of Hydrologist, Vol. 2. pp77-87.

Mamman, M. (1992): An analysis of fertility differentials in Kaduna Metropolis Unpublished PhD thesis, Dept of Geography, A.B.U, Zaria.

Mbonu, P.D.C., Ebeniro, J.O., Ofoegbu, C.O, and Ekine, A.S. (1991): Geoelectric sounding for the determination of aquifer characteristics in parts of the umuahia area of Nigeria; Geophysics, Vol. 56, No. 2, 284-291.

McCurry, P. (1976): The geology of the Precambrian to lower Paleozoic rocks of Northern Nigeria - A review in Kogbe, C.A. (Editor).Geology of Nigeria. Elizabeth Publication Company, Lagos. Nigeria. Pp. 15-40

Niwas, S. and Singhal, D.C. (1981): Estimating aquifer Transmissivity from Dar-Zarrouck parameters in porous media. Journal of Hydrology, 50. p 393-399

Jatau, B. S. (1998): The use of E.M. method in ground water prospecting in a basement complex area of Sabo, Kaduna State, National Engineering conference series Vol. 5 No 2 pp.86-92

Singh, K.P. (2005): Nonlinear estimation of aquifer parameters from surficial resistivity measurements: Hydrology and Earth System Sciences Discussions (HESSD) 2, 917-938. 